\title{
Bennie van der Walt: An expert in propagating the all- encompassing implications of the Christian world- and life view
}

\begin{abstract}
Book title:
'Like the first gleam of dawn: Reformational studies' - A Bennie van der Walt reader

Book Cover:

This new work was edited by Steve Bishop who also wrote the introduction to it, amended by an interview with Bennie van der Walt also conducted by the editor. These two pieces pave the way for an appreciation of the context and aim of the previously written book of Van der Walt. I am privileged to know Bennie since December 1969 when I met him for the first time on a cold Amsterdam winter day. Ever since it is good to have in Bennie a serious and honest reformational philosopher who is capable of disseminating in a constructive and penetrating way the basic contours of a Christian life- and worldview. Throughout his life Bennie has distinguished himself as a gifted scholar capable to articulate our reformational legacy in an understandable and profound way. This new work is no exception.
\end{abstract}

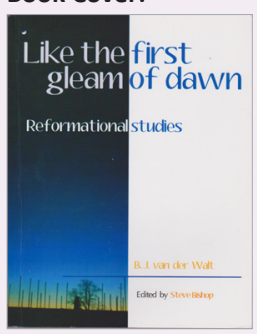

Author:

S. Bishop (ed.)

ISBN:

978-1-86822-607-8

Publisher:

Institute for Contemporary Christianity in Africa, 2011, R200.00

*Book price at time of review

Review title: Bennie van der Walt: An expert in propagating the all-encompassing implications of the Christian world- and life view

Reviewer:

Danie F.M. Strauss ${ }^{1}$

Affiliation:

${ }^{1}$ School of Philosophy, NorthWest University, South Africa

Email:

dfms@cknet.co.za

Postal address:

PO Box 339, Bloemfontein

9300 , South Africa

How to cite this book review: Strauss, D.F.M., 2013, 'Bennie van der Walt: An expert in propagating the allencompassing implications of the Christian world- and life view', In die Skriflig/In Luce Verbi 47(1), Art. \#180, 1 page. http://dx.doi.org/10.4102/ ids.v47i1.180

Read online:

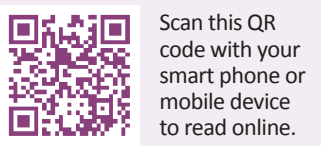

A brief look at the table of contents makes it immediately clear that Bennie articulated a reformational biblical worldview in the various articles. Without falling in the trap of stagnation and dogmatism he portrays the antithesis between Renaissance and Reformation as well as unbiblical traits in Calvin's view of the human being. This part of the book is concluded with a sound assessment of the position of women and marriages during the Middle Ages, during the times of Calvin and in our own time.

In the second part Bennie shifted the focus towards worldview and philosophy. This section takes the reader into a more detailed and systematic account of crucial insights and distinctions prevailing within the tradition of reformational philosophy. First of all it provies an analysis of the nature of a life- and worldview followed by an indication of how a world functions within each one of the various modal aspects of reality. In this part related issues are discussed, such as shaping a radical biblical worldview and biblical data for a Christian view of being human. Van der Walt appreciates the legacy of Abraham Kuyper for an understanding of our calling within human society. He also highlights a particular 'morning star' of the reformational worldview, A. Janse (1890-1960). This part is concluded with a special reference to the philosophical contribution of Theodor Vollenhoven.

Part 3 turns towards Africa, focusing on its cultural, moral and political dispensation, whilst Part 4 addresses the challenge for Christian scholarship. Van der Walt does this by telling the story of Thomas, who started out as a Christian, then moved on to be a Christian or a scholar, to a Christian and a scholar, until Thomas finally realised that his life is service to God encompassing all of life, including his calling as a Christian scholar. It is appropriate that this part concludes with reflections on the nature and aspirations of a Christian university. Part 5 contains an application to practical social issues such as a biblical understanding of culture and development, globalisation, economic normativity, poverty and wealth, the mystery of marriage, religious diversity, friendship and sport.

This work is accessible to any Christian and does not require specific academic training to appreciate and understand its perspective and call. Therefore it should be made accessible to Christians worldwide. It is therefore good news that this book will also be published as part of the Reformational Publishing Project by Paideia Press in Grand Rapids. 